\title{
Mezi Afrikou a Evropou: Etnografická studie ze života iregulérních imigrantů z Afriky, žijících v Neapoli
}

\author{
Kateřina Hojgrová \\ Katedra politologie a evropských studií, Univerzita Palackého v Olomouci, Křížkovského 12, 77900 Olomouc
}

Do redakce doručeno 14. dubna 2020; k publikaci přijato 18. listopadu 2020

\section{BETWEEN AFRICA AND EUROPE: ETHNOGRAFICAL STUDY OF THE LIFE OF IRREGULAR IMMIGRANTS FROM AFRICA LIVING IN NAPLES}

\begin{abstract}
This case study focuses on the issue of African irregular immigrants in Napoli in regard to the amendment of migration act by The Salvini decree. The paper discusses the concept of illegal and irregular migration, and it clarifies the clandestini as an alternative to the Italian environment. Qualitative method of ethnographic research, enriched by elements of phenomenology, has enabled to identify the main factors affecting the irregular immigrants (clandestine) lives in Napoli. Overall, 23 polo-structured interviews were conducted in autumn 2020 . The case study then maps the following: various processes the migrants have to undergo and experience since their arrival in Italy, conditions of their lives in admission centres of the first and second order, participation in the non-formal economy as a crucial pull factor, mutual relations within the African community, and last but not least the paper considers relations.
\end{abstract}

KEY WORDS clandestini; irregolar migration; Salvini's decree; african comunity; ethnographical research

\begin{abstract}
ABSTRAKT Př́padová studie se zaměřuje na téma iregulérních imigrantů z Afriky (immigrante clandestini) žijících v Neapoli, v tendencích novelizace migračního zákona tzv. Salviniho dekretem. Studie diskutuje nad konceptem iregulérní a ilegální migrace a přibližuje jejich alternativu v rámci italského prostředí. Kvalitativní metoda etnografického výzkumu s prvky fenomenologie umožnila identifikovat hlavní faktory života iregulérních imigrantů (tzv. clandestinů) v Neapoli, a to na základě dat sebíraných v rámci 23 polostrukturovaných rozhovorů, které byly provedeny na podzim roku 2019. Studie mapuje proces, kterým tito imigranti procházejí od svého př́ijezdu do Itálie, podmínky jejich života $\mathrm{v}$ př́ijímacích centrech prvního a druhého řádu, jejich participaci na neformální ekonomice jako hlavního pull faktoru, vzájemné vztahy uvnitř africké komunity a v neposlední řadě také sleduje jejich vztahy s majoritní italskou společností.
\end{abstract}

KLÍČOVÁ SLOVA Clandestini; iregulérní migrace; Dekret Salvini; africká komunita; etnografický výzkum

\section{TÉMA VÝZKUMU}

$\mathrm{Na}$ vrcholu migrační krize $\mathrm{v}$ roce 2016 připlulo $\mathrm{k}$ italským břehům více než tři sta tisíc osob (ISTAT 2017). I když se číslo nově příchozích v posledních třech letech stále snižuje, především díky striktní politice bývalého italského ministra vnitra Mattea Salviniho, Itálie díky své geopolitické poloze zůstává evropským nárazníkovým pásmem a otázka migrace je jedním $\mathrm{z}$ nejpalčivějších témat zdejší politiky i veřejných debat. Itálie byla dlouhou dobu označována jako země emigrační a bojovala spíše s odlivem obyvatelstva než s přílivem nových přistěhovalců. Imigrace se na regionální úrovni začala silněji projevovat až na přelomu 60. a 70. let minulého století. O deset let později pak začínala mít debata o imigraci celostátní charakter (Colucci 2018). Po dobu následujících čtyřiceti let v Itálii, kde se počet imigrujících osob stále zvyšoval, probíhalo zavádění nové migrační legislativy (Martelli 1990; Turco-Napoletano 1998; Bossi-Fini 2002; Bezpečnostní balíček 2009; Dekret Salvini 2019) a téma migrace se dostávalo do popředí. V průběhu tohoto období se Itálie potýkala jak $\mathrm{s}$ migrací regulérní, tak s imigrací iregulérní. Migrace iregulérní je však v posledních letech jejím problémem hlavním. 
Itálie je totiž zasažena spíše krizí smíšenou než uprchlickou, na rozdíl např. od Řecka, které bylo v letech 2015-2016 hlavní tranzitní zemí pro uprchlíky z oblastí válkou postiženého Středního východu. Trasou vedoucí přes území Itálie dále na území Evropské unie kontinuálně přicházely především osoby $\mathrm{z}$ afrického kontinentu, u kterých je mnohdy velmi obtížné rozlišit důvody, které $\mathrm{k}$ jejich migraci vedly. Jedná se $\mathrm{Z}$ velké části o imigranty ekonomické, kteři přicházejí kvưli lepším socio-ekonomickým podmínkám (Savino 2015, 26). Za cílovou skupinu studie jsem si proto vybrala osoby migrující z afrického kontinentu, a to ze dvou důvodů. Jednak proto, že v celoevropském měřítku jde o mediálně nejvýraznější skupinu vzhledem $\mathrm{k}$ imigraci do Itálie a také proto, že právě iregulérní imigranti $\mathrm{z}$ Afriky (clandestini ${ }^{1}$ ) představují $\mathrm{v}$ posledních letech největší skupinu připluvších $\mathrm{k}$ italským břehům (Governo italiano 2019). Mnoho z těchto osob pobývá na území Itálie iregulérně. Iregulérních imigrantů zůstává v Itálii podle odhadů organizace ISMU $\mathrm{z}$ konce roku 2018 více než 500000 , přičemž $71 \% \mathrm{z}$ těchto osob je ze třetích zemí (ISMU 2018). Podle odhadů Matteo Villa se navíc jejich počet může do roku 2020 zvýšit o dalších 140000 (ISPI 2018).

I přes fakt, že mnoho osob, které se dostanou na území Evropské unie iregulérně po Centrální stř̌edomořské cestě, využívá Itálii pouze jako tranzitní zemi, mnoho z nich na jejím území zůstává, nebo se na její území vrací. Italské prostředí je totiž pro iregulérně migrující osoby značně přívětivé. Děje se tak díky dobře fungující neformální „underground“ ekonomice, která je velmi výrazně hierarchicky strukturována dle národnostních skupin. Tato jedna $\mathrm{z}$ nejlépe prosperujících neformálních ekonomik v Itálii probíhá v jižním regionu Kampánie a její metropoli Neapoli, která je celosvětově známá svým vlastním fungováním pravidel, díky zapojení Camorry a dalších skupin organizovaného zločinu do oficiální mocenské struktury. Neapol zastává zároveň v Itálii specifickou pozici také díky jejímu starostovi, Luigimu de Magistrisovi, který navzdory př́stupu italské vlády stále proklamuje politiku otevřených dveří a nabízí lodím převážejícím imigranty bezpečné útočiště. Posledním dokladem tohoto př́stupu byla nabídka Carole Racketeové o možnosti ukotvit svoji lod' Sea watch 3 právě v neapolském př́stavu. Pro toto své postavení představuje Neapol neobvyklý př́pad nejen v rámci Itálie, ale i Evropy. Právě neobvyklost tohoto dění je pak podle typologie Roberta Yina důvodem k jeho prozkoumání, kdy „prozkoumání neobvyklého prŕípadu může přinést nové poznatky o obecných procesech“ (Yin 2014, 93).

Cílem této případové studie je proto zmapovat situaci iregulérních imigrantů (tzv. clandestinů) v oblasti Neapole, a to především s ohledem na jejich vlastní vnímání socio-ekonomických vztahů, zájem o vlastní sociální mobilitu a jejich budoucí směřování.

Při výzkumu bylo použito metody etnografického a fenomenologického výzkumu, především pak formy pozorování a polostrukturovaných rozhovorů. Současné migrační procesy jsou totiž velmi heterogenní z hlediska jejich trajektorií,

1 Italské označení nelegálních imigrantů viz diskuze níže účelu a trvání (Boccagni 2018). Právě hloubkové studium migrujících komunit $\mathrm{z}$ hlediska teritoria může nejlépe posloužit $\mathrm{k}$ pochopení migrace samotné.

Studium života osob s iregulérním statusem je poměrně novou disciplínou. V evropském akademickém prostoru se začalo objevovat až v polovině 90 . let (Meeteren 2014, 1). K pomalému rozvoji této oblasti výzkumu přispěla značnou měrou etická dimenze problematiky, protože iregulérní migrace byla na počátku výzkumu spatřována jako téma „too hot to touch“ (Duvell 1998 in Report of European Commision). V italském prostředí pak toto zdržení může být vyvoláno již zmíněným pozdním nástupem imigrace i udělováním „ex post“ masových amnestií pro regularizaci statutů migrujících osob, které se odehrávaly především mezi léty 1986 a 2002 (Sciortino 2009, 3). Jako jeden z prvních průniků do života migrantů v šedé zóně, byl prŕspěvek dvojice autorů Triandafyllidou a Kosic z roku 2006, který se ale soustředil na albánskou a polskou menšinu a jejich strategie pro přežití bez dokumentů. S postupem času a potřebou hlubšího poznání problematiky, etnografických příspěvků na téma života iregulérně migrujících osob přibývá. Mezi konkrétní práce, věnující se oblasti Kampánie a vybraným aspektům ze života migrantů bez dokumentů, patří především práce Hanse Luchta Darkness before Daybreak: African migrants living on the margins in southern Italy today, která je sondou do života ghanských rybářů na okraji společnosti. Mezi výrazné práce rozhodně patří studie australského politologa Nicolase Harneyho, který se ve svých pracích zabývá rovnou několika aspekty migrace v Neapoli, jako např́klad neformální ekonomikou přistěhovalců z Bangladéše nebo Afriky.

První část práce je věnována konceptu iregulérní imigrace $\mathrm{v}$ tendencích současné akademické debaty s ohledem právě na iregulérní imigraci do Itálie a Neapole. Ta čtenáře seznamuje nejprve se současným diskurzem, který se tohoto problému týká obecně. Následně se pak zabývá specifiky iregulérní imigrace v italském prostředí. Následuje metodologická část práce, která se zabývá metodou sběru dat a terénní prací. Třetí část studie reflektuje samotnou analýzu dat a výzkumná zjištění této studie.

\section{Clandestino, illegal nebo irregolar?}

Zkoumaným subjektem této studie jsou iregulérní imigranti z Afriky, žijící v Neapoli. K těmto osobám je vztažen pojem, který je v současné italské mediální, politické a veřejné debatě pojmem klíčovým. Je to pojem „clandestino“, který je zařazen i mezi pojmy v této studii.

Literatura, věnující se migraci osob obecně, rozděluje tyto osoby do dvou hlavních kategorií, a to na osoby migrující legálně nebo nelegálně. Výzkum osob migrujících legálně, na základě platných právních předpisů, není předmětem této studie, a proto zde není pojem ani cíleně operacionalizován. Pro účely studie je rozhodující zakořenění druhé skupiny osob migrujících ilegálně. Osoby nelegálně migrující jsou v zahraničí označovány škálou adjektiv illegal/ irregular/undocumented/unauthorized/ nebo globálně známými národními názvy 
jako je „sans-papiers“, a „clandestini“" (Triandafillidou 2016, 2). K tomu ale Triandafillidou dodává, že „že označení illegal ve vztahu k osobě není správné, protože žádná lidská bytost nemůže být nelegální, takové jsou pouze její činy." Takovéto označení pak navíc vyvolává stigmatizaci imigrantů, která je často kriminalizuje a spojuje s nelegální zločinnou činností. Pojem illegal se proto může vztahovat pouze $\mathrm{k}$ činu migrace, která ze své podstaty ilegální být může. Zpráva Evropské komise z roku 2008 pojem „illegal migration“ v její nejširší definici hodnotí jako migraci, která „není legální, nebo migraci, která je uskutečňována proti zákonuim o vstupu a pobytu do zeméc. V její úzké definici se pak jedná o „akt vstupu do zemè v rozporu s migračními zákony a týká se zejména aktu překročení hranice bez př́slušného povoleni" (Evropská komise 2008). Pojem Irregular pak podle této zprávy vznikl jako reakce na eticky nevhodné označení migrace jako illegal, které evokovalo spojení právě s kriminálním prostředím, přičemž ale skutková podstata porušení práv ze strany migrujících osob zůstává nezměněná. Pojem irregular migration tedy plně koresponduje s širokou definicí illegal. Jako termín může být navíc používán i v kombinaci přímo s osobou migranta, který $\mathrm{v}$ jakékoliv fázi vstupu nebo pobytu poruší některý $\mathrm{z}$ právních aktů. K překrývání širší definice illegal migration s irregular migration se kloní i právník Concas Alessandra, který je považuje z právního hlediska za synonyma a doplňuje je v rámci italského právního prostředí s rovnocenným výrazem migrace clandestini, tedy ilegální migrace (Concas 2017). S tímto tvrzením ale nesouhlasí jiní výkladoví právníci italského práva, kteří argumentují, že pojem clandestini se vztahuje pouze $\mathrm{k}$ činu osob, které porušily pravidla pro vstup na území Itálie a nemají žádné zákonné právo zůstat tam. Vzhledem $k$ tomuto tvrzení by se definice pojmu clandestini nejvíce podobala definici činu osob migrujících ilegálně, vzhledem k úzké definici ilegální migrace.

Vymezení pojmu clandestini, ve vztahu k označení skupiny osob je proto velmi nelehkým úkolem. I když jsou tímto pojmem $\mathrm{v}$ italském mediálním a politickém prostředí imigranti často označování, jeho definice neexistuje v italském, komunitárním ani mezinárodním prostředí, protože se jedná o ustálený výraz bez odborné konceptualizace. Př̀i hledání odpovědi na to, kdo by měl být za osobu - „clandestino“ považován, jsem tedy hledala odpověd $\mathrm{v}$ použití pojmu v legislativě. Pojem „immigrazione clandestino“ začal do italského právního systému pronikat $\mathrm{v}$ roce $1998 \mathrm{~s}$ prrítomností zákona „Turco-Napoletano“ (zákon č. 286/1998). V tomto zákoně se o „immigrazione clandestino" hovoří jak ve smyslu neoprávněného vstupu do země, tak i neoprávněném pobytu. Tento trend pokračuje i v legislativě zákona „Bossi-Fini“ (186/2002) i bezpečnostního balíčku 94/2009. Pojem immigrazione clandestino je v legislativě použiván jak ve smyslu porušení zákona o vstupu, tak i zákona o pobytu (viz např. cizinci, který „u svého vstupu nepožádal o povolení $k$ pobytu u questora do 8 pracovních dnů vyžadovaných zákonem; cizinci, kterému bylo povolení k pobytu zrušeno; cizinci, který je držitelem povolení $k$ pobytu, jehož platnost vypršela před více než 60 dny, během nichž nepožadoval jeho obnovu. "(leggioggi.it). Termí- nem „clandestini“ $\mathrm{v}$ tomto smyslu operují ve svých článcích i italské noviny La republica, Corriere della sera, Il Picollo. Proto jsem v této studii rovněž identifikovala clandestini v jejich širší verzi. Do mé cílové skupiny patřily jak osoby, které nedovoleně vstoupily do Itálie, tak i ty, které na jejím území žijí s neplatným či prošlým povolením k pobytu.

\section{Co, kde, jak a proč se děje $s$ „clandestinem“}

Faktorem, který je pro italského „clandestina“ určující, je jeho postavení v rámci systému. Určení toho, kdo je „clandestinem", to ve většině př́padů není ten moment, kdy se osoba vylodí na italském území. Určení statusu je proces, který dává migrantům čas a podle zákona nemůže být jejich žádost odmítnuta (viz dále). Proces vyhoštění může být zahájen až po vydání finálního rozhodnutí o zamítnutí žádosti o azyl, které ale může trvat i několik let. Ǩada „clandestinü“ těží právě z možné časové prodlevy a svého statusu žadatele nebo i neefektivnosti návratové politiky Itálie. Naprostá většina nově příchozích osob požádá o mezinárodní ochranu již $\mathrm{v}$ přijímacím středisku první tř́dy a od této chvíle čeká na vyř́zení svého statusu. V této studii jsem se zabývala procedurami, kterými migranti procházejí od své záchrany ve Středozemním moři po soubor práv, kterými disponují při svém pobytu v Itálii. Legislativa související s prijiímáním afrických imigrantů (ale i všech ostatních migrantů ze třetích zemí) a procedury, kterými na italském území procházejí se od účinnosti tzv. Dekretu Salvini ${ }^{2}$ v mnohém změnily. „Co se týče praxe, ta je v současnosti velmi zmatečná, protože se teprve vytvárí precedens, jak prri práci s imigranty postupovat" (zástupci organizace Je so pazzo Napoli).

\section{SYSTÉM PŘIJÍMACÍCH STŘEDISEK A PROCES UDĚLOVÁNÍ STATUSŮ}

Před platností Salviniho dekretu noví imigranti procházeli dvěma úrovněmi přijímacích středisek - prima a seconda accoglienza. Po vylodění byli imigranti shromážděni $v$ hotspotech $^{3}$, kde jim bylo poskytnuto lékařské ošetření, podstupovali zdravotní prohlídku, byli identifikováni a zařazeni do systému. Poté měli možnost požádat o azyl ${ }^{4}$ (ISPI 2018). $\mathrm{Z}$ hotspotu, kde mohou migranti pobývat oficiálně maximálně 72 hodin, byli poté prrevezeni do některého $\mathrm{z}$ vládních

2 Kontroverzní dekret o bezpečnosti a imigraci bývalého ministra vnitra Italské republiky, který vešel v platnost 4. října 2018.

3 Na konci roku 2018 byly na italském území 4 hotspoty: Taranto, Sicílie, Lampedusa, Pozzallo, Messina (https://www.lenius.it/sistema-di-accoglienza-dei-migranti-in-italia)

4 Mohla nastat i situace, kdy daná osoba nepožádá o azyl, a v tom, př́padě pokračuje do Identifikačního a vyhoštovacího centra CIE. Takováto situace, ale nastává zcela výjimečně. $\mathrm{V}$ roce 2018 mohli migranti v takovémto centru zůstat max. 90 dní. Těchto center je v Itálii 7: Bari, Brindisi, Caltanissetta, Turín, Rím a Trapani (tamtéž) 
přijímacích center prvního stupně (Cara, Cda, Cpsa) $)^{5}$, kde docházelo $\mathrm{k}$ další identifikaci, formalizaci žádostí a posouzení individuální situace jedince (Openpolis 2018). Z tohoto stupně přijímacích center pokračovali migranti do přijímacích center druhého stupně. Před Salviniho dekretem se mohli migranti dostat do dvou možných situací. První možností byla účast na Systému ochrany žadatelů o azyl a uprchlíků (SPRAR). Účast v tomto systému zajištovala imigrantům pomocí místních orgánů nejen sociální, právní a psychologickou péči, ale i účast na integračních projektech, kurzech italského jazyka, kulturních a sportovních aktivitách. Počet míst $\mathrm{v}$ tomto systému byl ale velmi omezený. Navíc zřizovatelem těchto programů byly obce, a ty mnohdy tato centra vůbec zřizovat nechtěly, i když byla financována ze státního rozpočtu. Tato nevole mohla být způsobená stranickým bojem, ale i jako populistické gesto vládnoucích antiimigračních stran. Proto vznikla na základě Zákona č. 142/2015 Sb. tzv. speciální přijímací centra (CAS). Tato centra sloužila v původním záměru při mimořádných situacích nebo nedostatku míst v centrech prvního nebo druhého stupně, postupně však začala sloužit jako náhrada umístění migrantů. Př́ijmová centra CAS jsou zřizována prefekturami v celé řadě hotelů, bytů a farem, přičemž životní podmínky migrantů v těchto zařízeních jsou mnohdy kritické a oproti SPRAR nabízí mnohem nižší záruku poskytovaných služeb. Ta je způsobena především finančním ziskem soukromých zřizovatelů CASů (Lenius 2020). Finanční kompenzace obdržená od ministerstva vnitra na jednoho migranta na den činila 35 eur. Soukromé subjekty, které nepodléhaly kontrole nakládání $s$ přidělenými financemi tak snižovaly standardy životních podmínek, s vidinou vlastního finančního prospěchu. Bussinessu s migranty využila také neapolská Camorra, která na něm postavila nové odvětví svého „podnikáni“.

Výše zmíněný Salviniho dekret oproti popsané situaci zrušil systém SPRAR, který nahradil novým systémem SIPROIMI (Systém ochrany pro př́jemce mezinárodní ochrany a pro nezletilé zahraniční osoby bez doprovodu). Tento systém již podle názvu poskytuje místo $\mathrm{v}$ integračním programu pouze osobám, které již získaly mezinárodní ochranu a nezletilým osobám bez doprovodu. Co se týče CASů, které jsou v reálu hlavními poskytovateli služeb pro imigranty, i zde proběhla změna. Tu lze nejlépe spatřit na alokaci finančních prostředků pro poskytovatele těchto zařízení, kdy se prvotní částka 35 eur na osobu snížila na 19 nebo 21 eur. Efektem této změny je bojkot nabídek některých poskytovatelů služeb CAS, kteří poukazují na neudržitelnost systému. Z ní ale těží mafiánští velkoposkytovatelé služby, kterým nezáleží na osobách migrantů, ale pouze na vlastním zisku.

Poslední a nejvýraznější změnou, kterou Salviniho dekret přinesl ve věci cílové skupiny iregulérních imigrantů je enormně narůstající trend zamítání udělování některého $\mathrm{z}$ typů me-

5 Přijímací centrum a první pomoc, Přijímací centrum, Přijímací centrum žadatelů o azyl). V roce 2018 jich bylo v Itálii celkem 12: Sicílie, Puglie, Benátsko, Friuli Venezia Giulia, Kalábrie, Emilia Romagna (tamtéž) zinárodní ochrany. Před vstupem dekretu v platnost mohl imigrant získat jeden ze tří typů ochrany, a to: status uprchlíka, doplňkovou nebo humanitární ochranu. Humanitární ochrana byla nejčastějším typem udělovaného statusu. Realitou zůstává, že tzv. humanitární status byl udělován celé řadě ekonomických migrantů, kteří by podle zákona neměli mít právo na žádný z typů ochrany. Byl však novým dekretem zrušen, což vedlo $\mathrm{k}$ dramatickému nárůstu počtu iregulérních imigrantů. Tento trend se projevil již za rok a půl platnosti dekretu, kdy se jejich počet zvýšil nejméně o 137 000. Jejich repatriace je navíc značně komplikovaná vzhledem $\mathrm{k}$ absenci potřebných dohod se zeměmi původu imigrantů (UNHCR 2019). Tento poslední bod tak reflektuje Salviniho snahu zahrnout všechny imigranty do jedné kategorie a v okázalém boji proti nim pak získat hlasy antiimigračních voličů.

Procedura udělování statusu začíná okamžikem požádání o mezinárodní ochranu. Prvním místem, kde je o ochranu žádáno je hotspot. Proceduru je však nutné zopakovat znovu po umístění do některého $\mathrm{z}$ center prvního přijmu. Tato žádost se podává na Questuře ${ }^{6}$ prŕslušného obvodu, kam byl migrant umístěn při svém př́jezdu do Itálie. Policejní ředitelství vydá dokument potvrzující žádost o mezinárodní ochranu a vytvoří o této skutečnosti zápis podle modelu C3, který obsahuje mnoho osobních otázek o životě migrující osoby, jeho rodinných poměrech, poměrech $\mathrm{v}$ zemi původu atd. Jak bylo zmíněno výše, zjevné neopodstatnění žádosti ale není důvodem $\mathrm{k}$ zamítnutí této žádosti. $\mathrm{V}$ okamžiku, kdy je osobě sestaven profil podle tohoto modelu, obdrží osoba povolení k pobytu jako čekatel, a to na období nejméně 6 měsíců, poté je ale povolení obnovováno až do doby, než je vydáno finální rozhodnutí, které potvrdí nebo zamítne žadatelovu žádost. Povolení k pobytu umožňuje žadatelům okamžitý přístup k lékařské péči a po dvou měsících rovněž slouží jako pracovní povolení. Je v této situaci žadatel stále „clandestinem“ nebo mu povolení $k$ pobytu zajištuje jakési alibi? ${ }^{7}$ O vydání rozhodnutí rozhoduje odborná komise, která sestává $\mathrm{z}$ expertů, kdy je posuzována politická, kulturní, sociální a náboženská situace $\mathrm{v}$ zemi jeho původu. Vydávání rozhodnutí se v posledních letech stalo mocenským nástrojem, který je do značné míry ovlivněn politickou ideologií policejního ředitelství i úplatkářstvím ze strany migrační mafie.

\section{PŘÍSTUPY}

Z hlediska metodologie je tento výzkum jedinečnou př́padovou studií s prvky etnografického a fenomenologického paradigmatu. Zkoumaným prŕípadem je v něm komunita Afričanů ilegálně migrujících do Neapole, která žije ve společnosti jedinečným životem. Jak bylo řečeno v úvodu, výzkum migrujících komunit je nutný pro pochopení migrace jako takové. Při

6 Policejní stanice

7 Migrant $\mathrm{z}$ hlediska práva dostal určitý druh statusu, prakticky se však jedná pouze o formální náležitost, která je $\mathrm{v}$ mnoha př́padech zjevně neopodstatněná. 
zkoumání konkrétní komunity, jsem použila smíšené metody, protože podle Fusche mohou kombinace použitých př́stupů zmírnit limity každé $\mathrm{z}$ nich a přispět tak ke komplexnímu pochopení problematiky, přičemž napomohou zmapování zkoumaného př́padu v širší perspektivě (Fusch 2017).

Př́padovou studii jsem použila pro její přednost, která spočívá v zachycení složitosti př́ípadu $\mathrm{v}$ jeho celistvosti (Hendl $2005,104)$. V tomto výzkumu jsem se snažila i o pochopení vzájemných vztahů $\mathrm{v}$ širších souvislostech, ne pouze $\mathrm{k}$ interpretaci jednoho konkrétního pohledu na zkoumanou problematiku. $\mathrm{K}$ výzkumu ekonomických, sociálních a kulturních vazeb uvnitř komunity afrických migrantů $\mathrm{v}$ Neapoli jsem prristoupila tak, jak to vnímá ve svých pracích Stake, kdy je cílem osvojení př́ípadu $v$ jeho žité realitě. $Z$ jeho pohledu se jedná o instrinsidní př́padovou studii, kdy se zabývám vybraným případem právě kvůli poznání jeho vnitřních aspektů (Ibid. 114). Pro širší pochopení př́padu je ale nutný nejen vnější pohled, ale i zaměření na jeho vnitřní aspekty. Př́ípad je proto částečně zkoumán i z perspektivy etnografického výzkumu, kdy se snaží odhalit jaké procesy vytváŕí sociální skutečnost zkoumané komunity. Jedná se o interpretativní neboli hermeneutickou etnografii, která zkoumá sociální interakci uvnitř̌ komunity. Jak poznamenává Geertz „Etnografický výzkum jako osobní zkušenost spočíá ve schopnosti vyznat se $\mathrm{v}$ nové situaci... porozumět kultuře jiných lidí znamená odhalit jejich normálnost, aniž bychom umenšovali jejich jedinečnost" (Geertz 2000, 24). V neposlední řadě reflektuje výzkum i prvky fenomenologického výzkumu, protože se zaměřuje i na subjektivní vnímání reality ze strany imigrantů. Fenomenologický prvek výzkumu byl zakomponován proto, že pro pochopení komunity ji musíme pochopit také z její vlastní perspektivy. Výsledkem fenomenologického př́stupu jsou informace, které „zní pravdivě» pro toho, kdo měl danou zkušenost $s$ daným fenoménem, a poskytuje vhled pro toho, kdo ji neměl (Hendl 2005, 128). Tedy v našem př́padě poskytne nejsubjektivnější vhled do života osob, iregulérně prríchozích a setrvávajících na území italské Neapole.

Toto komplexní pojetí výzkumu ze třech různých perspektiv nám umožní naplnit cíl práce, kterým je zmapování života afrických iregulérních imigrantů (clandestinů) na území Neapole.

\section{VÝZKUMNÁ TECHNIKA A VSTUP DO TERÉNU}

Svůj výzkum v komunitě nelegálně imigrujících osob na území italské Neapole jsem prováděla více než tři měsíce, a to v rozmezí zárí až prosinec 2019. Dostatek času mi poskytl možnost postupovat pomaleji a důkladněji, v několika fázích. V první fázi jsem se soustř̌edila na pozorování prostředí a navazování kontaktů. Prvotní kontakt jsem navazovala s imigranty různých národností a nesoustředila se pouze na komunitu Afričanů. Pro pochopení života jednotlivých skupin je totiž velmi důležité, spatřovat je i v komparaci s jinými.

Prvotním zdrojem dat této studie bylo využití informací, které jsem získala nezúčastněným pozorováním. Těmi nejdůleži- tějšími byly ty, které vedly $\mathrm{k}$ poznání části města, které obývají většinově nebo často imigranti $\mathrm{z}$ Afriky, jak se tito chovají $\mathrm{k}$ většinové společnosti, jaké jsou jejich denní činnosti apod. Tyto informace byly užitečné i při vytypovávání respondentů v lokalitách náhodného výběru.

Nejdůležitějším zdrojem dat pak byla data, získaná pomocí polostrukturovaných rozhovorů. Tyto rozhovory jsem uskutečňovala několika způsoby. Prvním z nich bylo oslovování vytypovaných osob na ulici. Díky zúčastněnému pozorování jsem zaznamenala několik míst ve městě, která jsou nejvíce obývaná osobami z Afriky. Jde především o hlavní vlakové nádraží Garibaldi a jeho blízké okolí - via Bologna, piazza Principe Umberto, Porta Capuana a Porta Nolana, lokality piazza Universita, via Forcella, via Toledo, via Duomo.

Druhým způsobem pořizování rozhovorů byly návštěvy místních organizací, pracujících s imigranty. Nejvíce nápomocná mi přitom byla organizace Jeso Pazzo a také misionářská pomoc při neapolské diecézi. Samotné rozhovory probíhaly $\mathrm{v}$ rámci dvou měsíců. Některé $\mathrm{z}$ těchto rozhovorů bylo velmi složité uskutečnit, protože mnoho respondentů bylo sice ochotno interview poskytnout, nicméně si nepřáli, aby bylo nějak zdokumentováno. Při sběru dat pomocí interview jsem všem účastníkům zaručila anonymitu, což bylo pro jejich postoj k rozhovorům rozhodující.

Celkem jsem provedla 23 rozhovorů s osobami z Nigérie, Senegalu, Ghany, Gambie, Mali, Sudánu, Maroka, Egypta, Pobřeží Slonoviny, Nigeru, Eritrei a Etiopie. Všichni respondenti byli mužského pohlaví, ve věku od 18 do 40 let. Neformální rozhovory jsem vedla i se ženami, ty ale většinou nebyly $\mathrm{k}$ rozhovorům ochotné a pouze vstupovaly do našeho rozhovoru s muži.

Významným zdrojem dat, které mi poskytli sami respondenti, byly jejich nejrůznější vizuální záznamy, jako např́klad videa nebo fotografie z Centro di accoglienza, prezentující životní podmínky jejich každodenního života. Někteři z respondentů byli ochotni ukázat potvrzení, nebo i dokumenty, kterými disponují. Tyto materiální záznamy byly velmi nápomocné pro vizuální dokreslení rozhovorů.

Takováto triangulace jednotlivých druhů dat mi poskytla širokou datovou základnu pro všechny tři zvolené př́stupy.

\section{LIMITY A PŘEKÁŽKY VÝZKUMU}

Hlavním úskalím výzkumu bylo prolínání jazyků, v nichž byly rozhovory vedeny, především však samotná bezpečnost výzkumníka, protože mnohé rozhovory byly vedeny v nestandardním prostředí. $Z$ těchto důvodů byla nutná ve většině př́ípadů prítomnost mého italského průvodce.

$\mathrm{Na}$ začátku většiny rozhovorů jsem musela respondentům velmi důkladně vysvětlit, za jakým účelem tento výzkum provádím, protože mnoho $\mathrm{z}$ nich mělo obavy $\mathrm{z}$ jeho pozdější mediální prezentace.

Pro vedení rozhovorů byla nutná vysoká míra empatie, která patří mezi nejdůležitější dovednosti tazatele (Kaufmann 2010, 60-61). 
Analýzu dat jsem poté provedla pomocí otevřeného kódování. Samotná analýza dat probíhala částečně již při sběru dat, protože bylo nutné dohledávat určitý typ případů. Protože jsem sběr dat prováděla sama, některé kategorie sociálního jednání se vynořovaly již během provádění rozhovorů. Vzhledem k otevřenému kódovaní jsem pracovala se všemi dostupnými daty a nereflektovala pouze předem navržené okruhy rozhovorů.

\section{ANALYTICKÁ ČÁST}

Život imigrantů z Afriky, jejich socio-ekonomická realita, kterou prožívají na území Neapole, je velmi často ovlivněna obdobím, které předcházelo jejich příchodu na italskou půdu. Psychicky a fyzicky vyčerpávající cesta, kterou migranti absolvovali na území afrického kontinentu a pak přes Středozemní moře nutně ovlivnila jejich následné sociální jednání v nové společnosti. Pokud se dostanou na evropskou půdu, jakákoliv forma života $v$ této nové společnosti je pro ně lepší než to, co prožili. Za nejproblémovější část cesty považovali respondenti období strávené v Libyi. Mnoho jich uvádělo, že jejich primárním záměrem nebylo $\mathrm{v}$ minulosti odejít přímo na evropské území, jak dřive mnohdy proklamoval Muammar Kadáfí, ale původně odešli ze svých domácích států s cílem, najít pro sebe lepší ekonomické prostředí právě v Libyi. Vrcholy migračních vln směrem do Evropy přes Centrální středomořskou trasu vždy započaly v návaznosti na nestabilní politickou situaci v Libyi. Toto tvrzení podporují data, která znázorňují korelaci mezi dvěma migračními krizemi a politickou nestabilitou v Libyi (Morone 2017, 1). Nestabilní politická situace a zhoršení hospodářské situace mělo za následek, že migranti začali být spatřování jako př́lišná ekonomická zátěž a jejich situace se dramaticky zhoršila (Xchange 2017). Respondenti uváděli zkušenost s nucenou prací, odepíráním svobody, rasovou diskriminací, mučením, bitím. Situaci nejlépe vystihuje zážitek $\mathrm{s}$ respondentem $\mathrm{z}$ Mali, který se odehrál ve večerních hodinách, kdy nedaleko od nás začaly vybuchovat zápalné lahve. Ptala jsem se respondenta, zda chce rozhovor ukončit, on mi ale odpověděl „Co, tohle? V Libyi jsem měl každý den zbraň u hlavy, tohoto se opravdu nebojím“.

\section{ILEGÁLNÍ EKONOMIKA}

Pro většinu migrantů, kteří přicházejí do Evropy přes Centrální středomořskou cestu, je hlavním pull faktorem zlepšení jejich ekonomického statusu. Itálie, specificky pak její jižní regiony ovládané největšími mafiánskými skupinami v zemi, jim nabízejí možnost participace na ilegální „underground ekonomice“, která jim zajištuje finanční zdroje i přes absenci povolení k pracovnímu trhu. Italská ilegální ekonomika, podle renomovaného soukromého výzkumného centra EURIPSES, odhaduje HDP z neformální ekonomiky pro rok 2016 na 200 miliard eur. Tento trend má rostoucí tendenci především od dluhové krize, kdy Itálie místo zvýšení produktivity, raději posouvá své aktivity směrem $\mathrm{k}$ ilegální činnosti. Tato skutečnost poté nahrává přílivu migrantů, kteří fungují jako levná pracovní síla na tomto trhu (Talani 2019, 172). V rámci analýzy se mi podařilo identifikovat hlavní způsoby získávání finančních prostředků, které vzhledem $\mathrm{k}$ pull faktoru patří mezi nejdůležitější formy sociálního jednání. Je nutné uvést, že respondenti, se kterými jsem vedla rozhovory, patřili z hlediska vnitřní sociální hierarchie k nejnižším vrstvám.

Pokud jde o neformální ekonomiku, existuje pro ně několik nejrozšířenějších druhů aktivit:

\section{Sezónní práce v zemědělství}

Téma nelegálního zaměstnávání migrantů $\mathrm{v}$ zemědělství není novým tématem a všímá si ho i Evropská komise, která ve svém Meziročním sdělení o strategickém přezkumu agendy pro migraci z roku 2017 uvádí toto zaměstnávání jako jeden $z$ hlavních pull faktorů migrace (Opensociety 2018). „Zaměstnáváni“"v zemědělství probíhá bud’ díky propracovanému systému Caporalato, ale migranti jsou najímání i individuálně drobnými zemědělci, kteří nabízí práci přímo „na ulici“, nebo přes kontakty již najatých migrantů. Přesto, že v Itálii není stanovena minimální mzda, i tak je zřejmé, že způsob vyplácení „mzdy“ hraničí s otrockou prací. Za celý den tvrdé dvanáctihodinové práce, si migrant odnese částku okolo 25-30 eur. Respondenti však uváděli i př́ipady, kdy jim odměna nebyla vyplacena vůbec. Vzhledem k ilegalitě najímání na práci neexistuje pro ně jakákoli odvolací instance.

\section{Nelegální práce na stavbách}

Podobná situace jako při najímání pracovníků do zemědělství, existuje i při práci na stavbách. Respondenti si nejvíce stěžovali na to, že při práci v tomto sektoru nedostali žádné ochranné pomůcky, ani jakékoli zabezpečení. Přestože někteří $\mathrm{z}$ nich měli zkušenost $\mathrm{s}$ tímto typem práce už z Afriky, popisovali, že najímatelé s nimi jednali jako s „otroky“. „Oni si myslí (najímatelé), že uděláme cokoli nám řeknou. Běž tam, dones to, udělej to. Když tam jsou bílí rovněž stejně najatí, myslí si, že nás můžou úkolovat a my budeme zticha" (respondent z Gambie). Mnoho respondentů má navíc stejnou zkušenost s vyplácením mzdy jako $\mathrm{v}$ zemědělství, kdy podle domluvy mají být mzdou vyplaceni např. po týdnu, ale stále se vyplácení odkládá. Nakonec dostanou pouze malou část slíbené odměny.

\section{Prodej drog}

Mezi migranty velmi „oblíbeným“ typem výdělku je prodej drog. Jde o jednoduchý typ výdělku, který nevyžaduje mnoho úsilí. Vytypovat prodejce není těžkým úkolem. Vyskytují se na náměstích a mezi uživateli v dobře známých lokalitách. Situace je vždy stejná. Migrant přichází do své „lokality“ve večerních hodinách a pouze sedí na svém místě. Nic nenabízí. Uživatelé migranty sami oslovují a celá situace netrvá více než minutu. Nejčastějšími prodejci drog bývají osoby z Nigérie, 
Ghany a Gambie. Když jsem se s nimi snažila uskutečnit rozhovor byli ochotni zodpovědět pár otázek, nikdy však nedovolili nahrávání rozhovorů. Policie v těchto lokalitách nikdy nezasahuje, prodejci jsou však kontrolováni a monitorováni bossem mafie, přičemž jednotlivé mafie kontrolují své určité lokality. Vše se odehrává pod kontrolou Camorry, která lokality takto kontroluje a ostatní jí musí platit „výpalné“. Při nedodržení podmínek pak často dochází k vyřizování účtů. Nejznámějším př́ípadem z oblasti je masakr v Castel Volturno $\mathrm{z}$ roku 2008, kdy byl usmrcen jeden ze členů italské mafie a šest afrických migrantů.

\section{Pouliční prodej „na stáncích“}

Jedním z nejčastějších způsobů, jak imigranti v Neapoli získávají zdroje obživy je prodej některého z typických prodejních artiklů, padělků světových značek, jako jsou kabelky, boty, sluneční brýle nebo elektronika. Co se týče módního zboží, prodej je hierarchicky strukturován a prodavači zboží nikdy nevlastní. Jsou pouhým článkem v síti, kdy výše jejich přijmu je závislá na ceně, kterou jsou schopni usmlouvat. Cena, za kterou musí zboží prodat je předem určena při přebírání zboží. Prodavači pak náleží rozdíl v ceně udané „shora“ a ceně, za kterou artikl prodají. Prodavači tohoto padělaného zboží na trhu jsou zřídka kontrolováni. „Tady kontrola probíhá tak jednou měsíčně. Víc ne. Policisté přijdou, nechají nás všechno sklidit, ale za pưl hodiny odejdou, a to je všechno" (respondent z Ghany). Prodavači si denně přijdou na 20-40 eur, v závislosti na množství prodaného zboží. Druhou skupinou jsou prodavači v pojízdných stáncích, kteří ale patří do hierarchicky vyšší skupiny, protože jsou většinou vlastníky prodávaného zboží a do prodeje vkládají vlastní kapitál. Tito prodavači svůj bussiness zajištují na frekventovaných místech. Jejich stánky jsou pojízdné, protože frekventovaná místa často kontrolují carabinieri, kteří na rozdíl od tržnice často prodejce konfrontují.

\section{Prodej kradeného/nalezeného zboží}

Jedním z typů prodejců jsou prodejci nalezeného/ukradeného zboží. Tito prodejci se vždy orientují na jeden konkrétní artikl, at už oblečení nebo elektroniku. Mnohdy získávají svůj prodejní artikl v kontejnerech na obnošené oblečení, vybíráním popelnic, nebo kradením značkového zboží např. v nočních klubech.

Na pomezí pouličního prodeje a žebrání je pak speciální kategorie prodejců/žebráků. Tito obligátní větou „hello my dear friend“ pak osobě nabídnou např. zapalovač, papírové kapesníky, nebo šperky. Pokud daná osoba nemá o zboží zájem, poprosí alespoň o drobné na kávu nebo na jídlo.

Způsobem, jak také vytypované osoby získávají finanční prostředky je i žebrání. Bud'př́mo, na veřejných prostranstvích jako jsou frekventované ulice, náměstí nebo vchody do supermarketů. Pokročilejším způsobem žebrání je oslovování kolemjdoucích a nabídka služeb. Typem těchto služeb je pak úklid ulic, nebo umývání čelních skel automobilů.

Kromě zdrojů $\mathrm{z}$ nelegálního bussinessu má každý imigrant po dobu, než je vyřízena jeho žádost o azyl, nárok na kapesné ve výši 2,5 eura za den. Toto kapesné mohou pak utratit podle svého uvážení, nicméně si ale stěžují, že za tyto peníze si nemohou koupit vůbec nic. Pravdou zůstává, že oficiálně mají nárok na stravu, hygienické pomůcky, zdravotní péči, telefonní kartu a další nezbytné pomůcky od zmiňovaných poskytovatelů CAS.

\section{CO S VYDĚLANÝMI PENĚZI? ANEB - ČÍM VÍC ZNAČEK, TÍM LÉPE...}

Protože iregulérní imigranti často žijí v centrech pro ně určených, která pro ně zajištují hlavní životní potřeby, mohou své finanční prostředky využít pro své další činnosti.

Většina $\mathrm{z}$ nich si při svém př́ijezdu do Itálie koupí nový telefon. Nové telefony vlastní i ti, kteří na první pohled v příliš dobré finanční situaci nejsou. Jak sami uváděli, telefon potřebují pro kontakt $\mathrm{s}$ rodinou a pro domlouvání pracovních příležitostí. Telefony získávají bud' tak, že si koupí použité telefony na ulici od prodejců, kteří prodávají kradené zboží, nebo si je pořídí u některého $\mathrm{z}$ operátorů na splátky. Ty ale pak často nesplácejí.

Nově př́íchozí dostanou při příchodu do Neapole mnoho rad od svých zkušenějších kolegů o tom, jak si opatřit nezbytné věci (viz kapitola sociální vztahy).

Často jde ale o věci ne potřebné, ale chtěné. Respondenti uváděli, že jsou schopni mnoho věcí si opatřit i na ulici. Všem osloveným respondentům ale záleželo na tom, aby byli pěkně a čistě oblečeni. Podle jejich slov jsou schopni si oblečení najít bud' na ulici a vyprat, nebo ho nakoupit na secondhandových tržištích, poblíž Porta Nolana. Často si vybírají oblečení světových značek a chtějí vypadat, jak sami uvádějí, „stylově“. Mnoho respondentů si stěžovalo na italskou stravu, která podle jejich slov neodpovídá tomu, na co jsou zvyklí. Strava jim způsobuje zažívací obtíže. Někteří proto využívají finančních prostředků k nákupu potravin, hotových jídel, cigaret a také alkoholu. Alkohol není záležitostí pouze nemuslimů, požívá jej i velká část respondentů, kteří uvedli jako svoje náboženství islám. „To Alláh nevidí" (respondent ze Senegalu s úsměvem na rtech).

Podle tvrzení respondentů je zvykem zasílat část vydělaných peněz do domovských zemí. Ti, kteři jsou mladší, většinou nemají otce, a jako od nejsilnější mužské části $\mathrm{v}$ rodině se od nich očekává, že se postarají o zbytek rodiny. Jak bylo zmíněno výše, většina $\mathrm{z}$ nich původně hledala práci $\mathrm{v}$ Libyi a až v průběhu tamní občanské války se vydali kvůli nepříznivým podmínkám do Evropy. Mnoho z respondentů má rovněž ve své domovské zemi vlastní rodinu, jedno až dvě děti, a posílají peníze na jejich vzdělání a náklady s tím spojené „... aby dítě nemuselo mít stejnou budoucnosti jako já.“ Posílají domů částku v rozmezí 50 až 150 eur měsíčně, přičemž tato částka $\mathrm{v}$ zemi původu podle jejich slov zabezpečí většinu výdajů rodiny.

Podle respondentů bývá ale největší položkou v jejich rozpočtu ubytování. To jsou nuceny platit jak osoby, které mají propadlé povolení k pobytu, tak nově příchozí, kteří přišli o mož- 
nost pobývat v CASu. Někdy totiž nastává i situace, kdy jsou osoby vypovězeny z CASů. Dochází k tomu zejména ze tří důvodů. Za prvé pro porušení pravidel, kdy jsou imigranti povinni se hlásit každý den oproti podpisu ve svém CASu (pokud jsou vypovězeni nemají právo na umístění v žádném jiném centru, i když proces rozhodování o jejich právním statutu stále probíhá), nebo pro porušení pravidel chování (rvačky, drogy). Druhým př́padem je situace, kdy se stanou jednoduše nepohodlným pro provozovatele CASu, protože si např́klad často stěžují na podmínky v centru, zacházení, neposkytnutí lékařské pomoci atp. („Pokud se ti tady nelíbí, táhni zpátky do Afriky“). Žádný kontrolní mechanismus tohoto postupu neexistuje. Provozovatel centra totiž zavolá policii, a ta ve většině případů uvěrí provozovateli centra a osoby vykáže, čímž tyto ztratí nárok na pobyt v centru. Podobné situace se stávají i v hromadném měřítku. $\mathrm{V}$ této situaci musí takto postižený migrant sáhnout do vlastní kapsy a zaplatit si ubytování, nebo zůstat na ulici. Imigranti si sami své ubytování nepronajímají. Pronájem vždy probíhá přes třetí osobu, většinou stejné státní příslušnosti, a ta pronajímá byty dále. Ubytování stojí nejméně 90 eur na měsíc (např̀ via Forcella) do 150 eur. Osoby bydlí ve většině případů ve sdílených pokojích.

\section{SOCIÁLNÍ VZTAHY}

Sociální vztahy se budují až v Neapoli, nebo se také obnovují kontakty, které mají iregulérní imigranti ve státech Evropy už ze států domovských. Podle respondentů jich mnoho odjíždí přes Středozemní moře samo. Se svými druhy, které potkali v některých fázích cesty se př́liš nesbližují, i když jsou všichni na „stejné lodi“. Jak uváděli, pokud by navázali kontakt $s$ některou z dalších osob a projevili vzájemnou empatii, mohlo by je to stát život. „Když někomu dojde na cestě přes Saharu voda, nedám mu svou, brzy mi totiž dojde taky. Staral jsem se jen sám o vlastní přežitíc (respondent z Gambie). Jak bylo zmíněno výše, v Neapoli se respondenti už stávají součástí místní africké komunity, která je dále diferenciována podle kulturních, jazykových, a v neposlední řadě i náboženských skupin. Africká imigrantská komunita je ovládána jejich bossy, kteří koordinují jednotlivé druhy neformální ekonomiky, zaštitují pronájmy nemovitostí, vyjednávají s př́slušníky ostatních mafiánských sítí. Mezi imigranty ale fungují výrazně přátelské vztahy a vzájemně se o sebe starají. Radí si, jak mají vyřídit komunikaci $\mathrm{s}$ úřady, starají se o sebe $\mathrm{v}$ př́ípadě zdravotních problémů a poskytují si vzájemnou oporu. Ti, kteři přijdou do Evropy sami, žijí ve skupinách práátel, kteří tvoří jakési „rodiny“.

\section{KOLIK JAZYKU゚ UMÍŠ, TOLIKRÁT SI ČLOVĚKEM}

Znalost jazyků hraje klíčovou roli při navazování sociálních vztahů uvnitř africké komunity v Neapoli. Bývalá koloniální př́slušnost domovských států migrantů formuje v komunitě přátelské i pracovní vztahy. Italština se nepoužívá, lidé do jis- té míry spoléhají na jazykové vybavení, které znají. Není výjimkou, že některé osoby jsou v Itálii i několik let, a přesto její jazyk neovládají, není to v každodenním životě ani nutné. Vystačí si s několika frázemi, které používají pro obchod, a to jim stačí. Po svém př́iezdu do Itálie mají imigranti v komunikaci $s$ úředními orgány i např. při zdravotnické péči právo na překladatele ze svého rodného jazyka, stejně tak poté $\mathrm{v}$ prrípadě, kdy jsou zařazeni $\mathrm{v}$ systému jednoho $\mathrm{z}$ př́ijmových center. Na státní úrovni i na úrovni neziskových organizací je vyučována italština, pro imigranty je však problematické se kurzů účastnit, protože čas raději věnují výdělečné činnosti „ten kurz je třikrát týdně a dopoledne, to já nemůžu chodit, protože pracuji“ (respondent měl na mysli prodej na trhu). Výjimkou nebyl ani imigrant z Maroka, který žije v Itálii 9 let a stále hovoří italsky jen na úrovni základních frází. Nejlepším způsobem, jak se mohou imigranti italsky naučit, je přátelská interakce s italskými obyvateli. To se potvrdilo na prrípadu Abdula Azise ze Senegalu, který byl schopen se jazyk naučit za tři měsíce, a to pouze komunikací s italskými přáteli. Z hlediska jazykových kompetencí mají nejlepší podmínky imigranti například z Gambie, Nigérie a Ghany, mluvící plynně anglicky, světovým jazykem číslo jedna. Zároveň jsou spojeni se svými nejzápadnějšími sousedy „mandinkou“ a jejími př́buznými jazyky „bambarou“ a „dioulou“. Někteří mají výhodu ve znalosti francouzštiny, která je spojuje s migranty ze severní Afriky.

\section{NENÍ AFRIČAN JAKO AFRIČAN, ANI BRATR Z NIGERIE NEMUSÍ BÝT BRATREM}

Uvnitř africké komunity existuje řada hierarchických zákonitostí, které jsem při rozhovorech s respondenty identifikovala. Afričané ze Subsaharské Afriky pocitují otevřený rasismus ze strany Afričanů ze severní Afriky. Ti mají podle Subsahařanů pocit, že do Evropy patří více a že si zaslouží ze strany Evropanů lepší podmínky k životu. „No oni se berou jako něco lepšího, a ukazují nám to, že tady šéfuji“" (respondent z Gambie). S tímto tvrzením ale „seveřané“ nesouhlasili, a naopak se ho snažili většinou vyvracet. Částečně ale tuto premisu, že mají „,seveřané“ lepší podmínky, potvrzuje fakt, že se viditelně tolik nepodílejí na žádném $\mathrm{z}$ výše uvedených typů neformální ekonomiky, i přes fakt, že imigranti z této oblasti se pohybují na předních příčkách počtu imigrantů dle národnosti. (Statista 2020). Mưže to být způsobeno jejich lepší jazykovou připraveností, protože Afričané ze severu oproti svým jižnějším sousedům ovládají často italštinu už před př́ijezdem do Itálie, ale také historickým kontextem, protože migrace ze severní Afriky do Itálie započala mnohem dříve, proto Afričané ze severu mají vytvořené v evropských státech funkčnější, lépe organizované diaspory. $\mathrm{V}$ neposlední řadě je to také jejich vyšší sociální mobilitou a připraveností orientovat se v novém prostředí a využívání kliček v zákonech.

Výrazným znakem při rozhovorech s respondenty bylo jejich silné pouto $\mathrm{k}$ náboženství, kdy kromě jednoho respondenta ze Senegalu, všichni navštěvovali některé $\mathrm{z}$ modlitebních 
míst, podle své víry. I přesto, že se snažili respondenti působit dojmem, že jsou ke všem přátelští a nikdo jim nevadí, když jsem v rozhovoru o náboženství zašla hlouběji, např. u respondentů, kteří vyznávali křest̉anskou víru, mnohokrát se projevila antipatie ve vztahu $\mathrm{k}$ vyznavačům islámu. Tento znak byl nejvíce patrný u osob z Nigérie, kteří vzájemné náboženské antipatie pocitovali nejvíce: „no, s těmi já se nebavím, nechci s nimi nic mít, nejsou to dobří lidé“ (respondent z Nigérie).

\section{SOCIÁLNÍ VZTAHY S MAJORITNÍ SPOLEČNOSTÍ}

Je evropská manželka benefitem zákona o sloučení rodin? Mexická a kanadská migrace do USA zná fenomén zelených karet. Mezi imigranty $\mathrm{z}$ afrických zemí $\mathrm{v}$ Itálii se rozmáhá novodobý fenomén - využívání zákona o sloučení rodin. Většina afrických migrantů chce evropskou ženu. Je tento trend otázkou nějaké právní vypočítavosti nebo skutečně se jednoduše africkým mužům líbí ženy evropského typu? Migranti jistě v určité míře kalkulují se směrnicí Evropské unie 2003/86/ES o právu na sloučení rodiny. Otázkou zůstává , zda jsou natolik orientovaní i v jejich klíčových podmínkách, konkrétně směrem k podmínce „že o sloučení může požádat držitel povolení k pobytu alespoň na jeden rok a který má zákonnou možnost, že získá právo trvalého pobytu“ a výslovně se nevztahuje na „rodinné příslušníky občana $\mathrm{EU}$, ani na státní příslušníky zemí mimo EU, kteří jsou žadateli o přiznání právního postavení uprchlíka a o jejichž žádosti nebylo pravomocně rozhodnuto, nebo kteří požívají nějaké dočasné formy ochrany“ (Směrnice 2003/86/ES o právu na sloučení rodiny).

\section{IREGULÉRNÍ IMIGRANTI JAKO BUSSINESS PRO CAMORRU?}

Jak bylo zmíněno výše, $\mathrm{z}$ hlediska specifičnosti případu vzhledem k teritoriu, je ten neapolský ovlivněn prrítomností hluboce zakořeněného organizovaného zločinu a mafiánských organizací. Kampánijská Camorra využila migrační krize jako dalšího způsobu př́ijmu a na obchodu s imigranty vydělává sta tisíce eur. Mezi nejrozšířenější způsoby bohatnutí pak patř́i spolupráce či vzájemný vztah s mafiemi ze třetích zemí, kterými jsou tolerance a výkupné v drogových lokalitách či pronájmy těchto lokalit, kde poskytují např. sexuální služby přistěhovalkyně ze třetích zemí. Druhým nejčastějším způsobem, jak mohou kriminální sítě ekonomicky využít imigrantů je zřizování výše zmiňovaných CASů.

\section{ITALOVÉ, P̌̌ÁTELÉ JEN DO URČITÉ MÍRY}

Iregulérní imigranti, žijící na území Neapole, jsou většinovou společností tolerováni do té míry, která je pro Italy výhodná. Využívají jejich služeb především díky jejich zapojení v neformální ekonomice a prodeji drog. Imigranti čelí ze strany Italů rasismu, je na ně pohlíženo často jako na osoby „dru- hé kategorie“. Z jejich zkušeností vyplývá, že rasismus není otevřený, jde spíše o přehlížení, o horší navazování vzájemných vztahů, a způsoby, jakými s nimi Italové jednají: „oni se s námi tolik do řeči nedávají, spíš je to o tom, že nám nějak neubližují, ale ani nejsou ochotni se přátelit, protože jsme černí. Většina respondentů měla s většinovou společností špatné zkušenosti nejčastěji $\mathrm{v}$ „pracovním prostředi“", kdy, jak bylo zmíněno výše, jsou mnohdy obětmi vykořistování a otrocké práce. Druhým prrípadem, kdy dochází k útlaku je jejich pobyt v CASech. Tam jsou často utlačováni a žijí v nevyhovujících podmínkách. Pokud se obrátí na poskytovatele CASů, např́íklad v případě nutnosti lékařského ošetření, často se setkávají pouze s hrubým odmítnutím. To má za následek často těžká onemocnění jako je tuberkulóza nebo neléčená HIV. Jediným činitelem, jak je možné proti této situaci zakročit, je činnost neziskových organizací, které docházejí do CAS ̊̊ a situaci monitorují. Lékařské ošetření je sice zakotveno zákonem, nicméně pokud se imigrant vůbec $k$ lékaři dostane, je často přednostně ošetřena osoba $\mathrm{z}$ většinové společnosti. „Já jsem čekal v nemocnici s kamarádem 8 hodin, pak se na něho doktor tedy podíval a poslal ho domů, že mu nic není, ale na druhý den už měl velikou horečku a museli jsme ho tam odvést a měl zápal plic“ (respondent ze Senegalu). Pokud jde o nějaký druh pomoci, imigranti si často velmi chválili právní pomoc s vyřizováním dokumentů, nebo i práci neziskových organizací, jako je třeba Je so Pazzo. „Tady máme jazykový kurz, pomáhají nám se všemi dokumenty, je to takové útočiště“".

\section{ZÁVĚR}

Výzkum problematiky iregulérních imigrantů (clandestinů), přicházejících Centrální středomořskou cestou do Itálie, je poměrně málo popsanou problematikou, která ale vyžaduje mnoho pozornosti pro svou jedinečnost a mnoho doprovodných aspektů. Tuto problematiku je nutné poznat, pochopit a monitorovat jako samostatnou disciplínu.

Snahou této práce bylo jednak představit tenkou hranici mezi regulérním a iregulérním přistěhovalectvím, přispět do debaty o definování příčin a následků iregulérní imigrace vůbec, se snahou ozřejmit procesy, kterým jsou vystaveni imigrující lidé právě v Itálii, a to v kontextu nedávné novelizace italské legislativy (Salviniho dekret), která se problematikou zabývá. $\mathrm{V}$ duchu a kontextu právě této novelizace italské legislativy se totiž zdá, že se Itálii př́liš nedaří adekvátně reagovat na fenomén právě iregulérního přistěhovalectví a kdy částečně selhává řešení této krize i za využití všech možných legislativou nastolených instrumentů.

Hlavními problémy, jak naznačuje autorčin výzkum problematiky iregulérních imigrantů (clandestinů), je zapojení $\mathrm{v}$ neformální ekonomice, nedostatek lidských kapacit pro kontrolu přijímacích procesů imigrantů i hluboce zakořeněná přítomnost organizovaného zločinu. To vše, i přes veškerou snahu, neumožňuje Itálii dosáhnout lepších výsledků v udržitelné migrační politice. 
Budoucím možným tématem výzkumu by bylo provedení longitudinální studie chování iregulérních imigrantů z hlediska jejich sociální mobility a vzdělávání a zjistit, zda se po získání dlouhodobého statusu jejich život změní a oni se dokáží adaptovat do přijímací společnosti, anebo zda i přes nové možnosti i nadále zůstanou stále někde na pomezí regulérnosti a iregulérnosti.

\section{LITERATURA}

Boccagni, P. (2018): Migration and the search for home mapping domestic space in migrants everyday lives. Basingstoke: Palgrave MacMillan.

Cambiamenti del decreto sicurezza e immigrazione. (2019): [Online] UNHCR. [cit. 15.1. 2020] Dostupné z https://www.unhcr.it/risorse/carta-di-roma/ fact-checking/2019-gennaio-cambiamenti-del-decreto-sicurezza-immigrazione.

Che cosa sono i Cas, lo Sprar e gli Hotspot. (2018): [Online] Openpolis. [cit. 20.1.2020] Dostupné z https://www.openpolis.it/parole/che-cosa-sono-i-cas-lo-sprar-e-gli-hotspot.

Colluci, M. (2018): Per una storia del governo dell'immigrazione straniera in Italia: dagli anni sessanta alla crisi delle politiche. Meridiana 32(1), 9-36.

Concas, A. (2017): Il reato di immigrazione clandestina. [Online] Diritto \& Diritti [cit. 27.12.2019] Dostupné z https://www.diritto.it/il-reato-di-immigrazione-clandestina.

Ethical issues in irregular migration research. (2008). [Online] Evropská Komise. [cit 16.12.2019]. Dostupné z https://ec.europa.eu/migrant-integration/index.cfm?action=media.download\&uuid $=2$ A981619-FBC3-16FC-20988E903B456E97.

Cruscotto statistico giornaliero. (2019): [Online] Governo di interno Italia [cit. 12.12. 2019]. Dostupné z http://www.libertaciviliimmigrazione.dlci. interno.gov.it/sites/default/files/allegati/cruscotto_statistico_giornaliero_19-11-2019.pdf.

Geertz, C. (2000): Interpretace kultur: vybrané eseje. Praha: Sociologické nakladatelství (SLON).

Harney, N. (2011): Accounting for African migrants in Naples, Italy. Critical Perspectives on Accounting 22 (4), 644-653.

Hendl, J. (2005): Kvalitativní výzkum: Základní metody a aplikace. Praha: Portál.

Is italian agriculture a pull factor for irregular migration- and if so, why? (2018) [Online] Opensociety. [Cit. 27.1. 2020]. Dostupné z https://www.opensocietyfoundations.org/uploads/ba12312d-31f1-4e29-82bf-7d8c41df48ad/ is-italian-agriculture-a-pull-factor-for-irregular-migration-20181205 pdf.

Il sistema di accoglienza dei migranti in Italia, spiegato per bene. (2020): [Online] Lenius.[Cit. 1.2.2020] Dostupné z https://www.lenius.it/sistema-di-accoglienza-dei-migranti-in-italia.

Kaufmann, J. (2010): Chápající rozhovor. Praha: Sociologické nakladatelství SLON

Libyan Detention Centers - A Legal Analysis. [Online]. Xchange Foundation. [Cit.12.12.2019] Dostupné z http://xchange.org/map/Libya_DC.html
Lucht, H. (2011): Darkness before Daybreak African Migrants Living on the Margins in Southern Italy Today. University of California Press, Meeteren,

Migranti la sfida dell integrazione. (2018): [Online] Istituto per gli studi di politica internazionale. [Cit. 12.12.2019]. Dostupné z https://www.ispionline.it/sites/default/files/pubblicazioni/paper_ispi-cesvi_2018.pdf.

Morone A. (2017): Policies, Practices, and Representations Regarding Sub-Saharan Migrants in Libya: From the Partnership with Italy to the Post-Qadhafi Era. In: Gaibazzi, P. - Dünnwald, S. - Bellagamba, A. (eds) EurAfrican Borders and Migration Management. New York: Palgrave Series in African Borderlands Studies. Palgrave Macmillan. doi. org/10.1057/978-1-349-94972-4_6.

International and internal migration. (2017): [Online]Instituzione nazionale di statistica. [Cit 17.12.2020] Dostupné https://www.istat.it/en/archivio/213837.

Savino, R. (2017): La crisi migratoria tra Italia e Unione europea. Diagnosi e prospettive. Napoli: Editoriale Scientifica.

Smèrnice Rady 2003/86/ES ze dne 22. září 2003 o právu na sloučení rodiny. [Online]Směrnice Evropského Parlamentu. [Cit. 20.1.2020] Dostupné https://eur-lex.europa.eu/legal-content/CS/ALL/?uri=CELEX\% 3A32003L0086.

Sciotrino, G. (2009): Fortunes and miseries of Italian labour migration policy. [Online] Centro studi di politica internazionale.[cit. 10.12.2019]. Dostupné $\mathrm{z}$ https://www.cespi.it/sites/default/files/documenti/country_mig-italia-sciortino.pdf.

Number of immigrants arrived in Italy between 2019 and 2020, by nationality. [Online] Statista [cit. 28.2.2020] Dostupné https://www.statista.com/ statistics/779300/number-of-immigrants-landed-in-italy-by-nationality.

Talani, L. (2019): The Italian Way to Globalisation: Moving to the Dark Side Between Irregular Migration and the Underground Economy. 171-199 In: Talani, L. - Roccu, R. (eds.) The Dark Side of Globalisation. Cham: Palgrave Macmillan

Triandafyllidou, A. (2016): Irregular Migration in Europe in the Early 21st Century. 1-23, In: Triandafyllidou, A. (ed.) Irregular Migration in Europe: Myths and Realities. Farnham: Ashgate Publishing Limited.

Yin, R. (2014): Case Study Research: Design and Methods. London: SAGE Publications.

\section{AUTORKA}

Hojgrová, Kateřina je doktorandkou na katedře Politologie a evropských studií Univerzity Palackého v Olomouci. Vystudovala obor Evropská studia se zaměřením na evropské právo. Mezi hlavní oblasti jejího výzkumu patří téma iregulérní imigrace do Itálie po Centrální středomořské cestě. Hlavními metodami jejího výzkumu jsou semistrukturované rozhovory. V posledních letech participuje na evropském projektu Občanský průkaz, který se zaměřuje na začleňování nových témat do výuky na středních školách. Autorka připravuje sekci, která se bude zabývat právě migraci.

Kontakt: Hojgrova.k@seznam.cz 